\title{
Should azoospermic patients with varicocele disease undergo surgery to recover fertility?
}

\author{
Leonardo de Souza Alves ${ }^{1 *}$, Francisco Batista de Oliveira² \\ ${ }^{1} \mathrm{MD}$, Urologist, Faculdade de Ciências Médicas de Minas Gerais (FCM-MG). Director of Procriar - Instituto de Urologia e Andrologia. Full Member of the Sociedade Brasileira de Urologia (SBU), the American Urological \\ Association (AUA), and the American Confederation of Urology (CAU). Full Member of the Colégio Brasileiro de Cirurgiões (CBC), Belo Horizonte, MG, Brazil \\ ${ }^{2} \mathrm{MD}$, Gynecologist, Endocrinologist, FCM-MG, Belo Horizonte, MG, Brazil
}

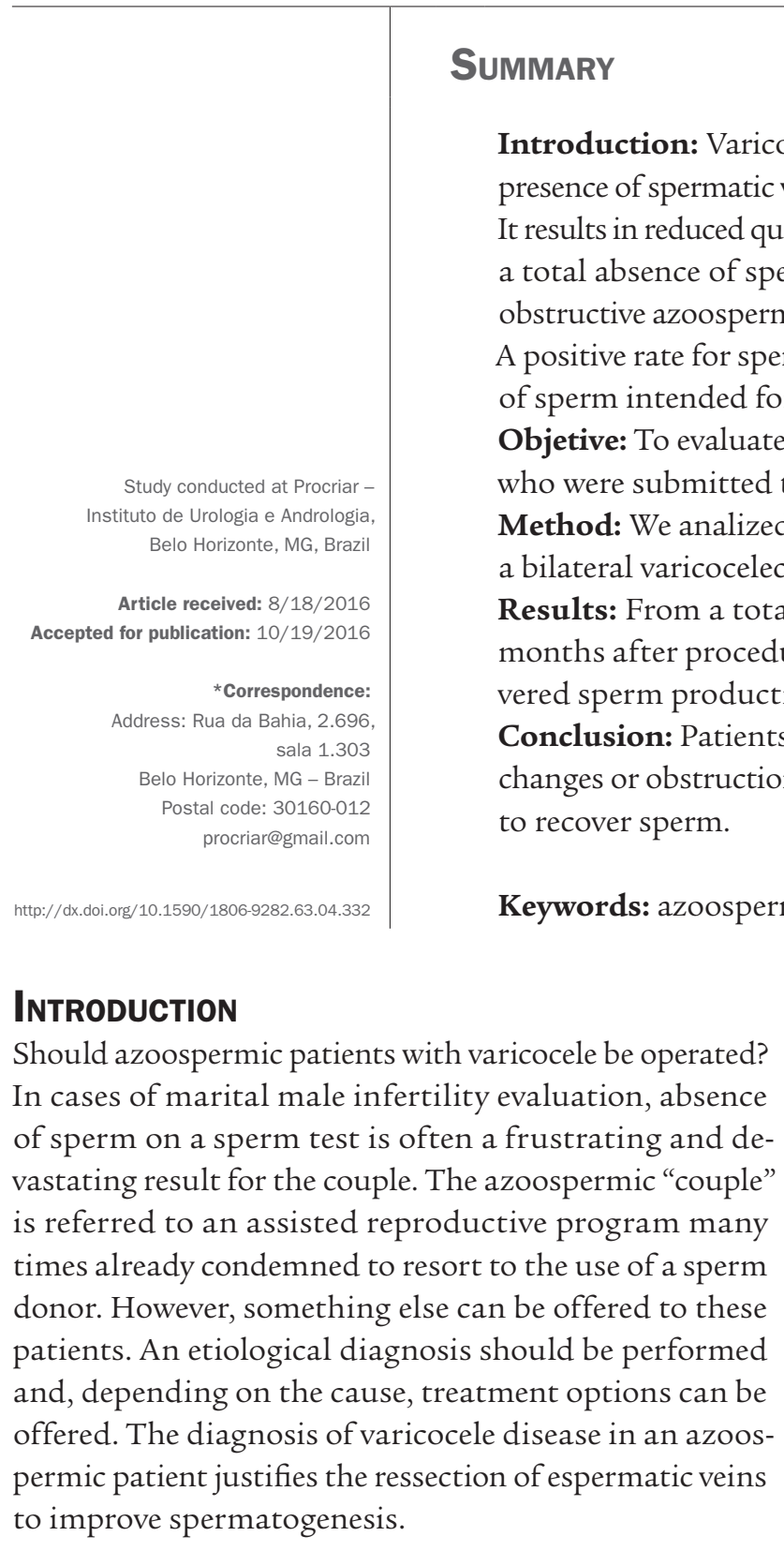

\section{Objective}

To evaluate patients with non-obstructive azoospermia (NOA) and varicocele undergoing bilateral surgical correction for recovery of sperm production.

\section{Method}

In a retrospective study conducted from 2002 to 2015 at a private urologic service, we analyzed 25 patients with combined varicocele and azoospermia (the inclusion criteria). The patients had two consecutives sperm samples showing absence of sperm cells, collected within an interval of 3 to 5 days. The semen volume should be greater than $3 \mathrm{~mL}$ in the studied group. Physical examination identified presence of vas deferens and uni or bilateral varicocele. The results of laboratory tests of FSH, LH, total testosterone and fructose were within the normal range. All selected patients underwent karyotyping and Y-chromosome microdeletion analysis. All 25 patients underwent bilateral surgical repair of varicocele. Sub-inguinal approach assisted by loupe magnification was performed by the surgical team. They all received the pre-surgical guidelines and signed an informed consent form. Patients were discharged from the hospital on the same day as the surgical procedure. The 
first sperm count was conducted 60 days after surgery, and subsequently repeated every 60 days.

\section{RESULTS}

Of the 25 patients, 10 (40\%) presented bilateral varicocele on physical examination. Left varicocele was identified in nine (36\%) patients, and six (24\%) had right-sided varicocele only. Sperm was found in three (12\%) patients treated surgically, four months after the procedure. Six months after surgery, sperm was identified in five $(20 \%)$ patients. After one year of follow-up, only five (20\%) patients had sperm in the ejaculate (Table 1). None of the five patients presented testicular volume reduction in pre-op. The concentration of sperm in the patients operated reached 0.5 to 12 million $/ \mathrm{mL}$ ( $\mathrm{Vr}>20$ million $/ \mathrm{mL}$ ). Out of the total of 25 patients, three (12\%) had changes in karyotype, and two (8\%) had Y-chromosome microdeletions.

\section{Discussion}

The male factor is responsible for about $40 \%$ of cases of marital infertility. A diagnosis of azoospermia is made in up to $15 \%$ of infertile men. ${ }^{1,2,4,6,7}$ Non-identification of sperm in the semen should always be investigated. A differential diagnosis between obstructive and non-obstructive azoospermia is fundamentally important for the treatment and prognosis of patients. ${ }^{1,2,4,8} \mathrm{FSH}, \mathrm{LH}$, total testosterone and estradiol levels combined can demonstrate the testicular function. Last but not least, measuring the level of fructose in semen offers evidence for obstructive diagnosis. ${ }^{1,2,4,6,8}$

Researching the medical history is crucial and can guide the diagnosis:

1. history of cryptorchidism in childhood and if and when it was corrected;

2. history of sexually transmitted diseases;

3. previous contact with gonadal-toxic agents or the use of exogenous androgen, very common in the absence of sperm;

4. story of retrograde ejaculation (in diabetics, patients with bladder voiding disorders, changes in patients undergoing prostatic surgeries) will identify patients with sperm in post-ejaculation urine analysis.
Karyotype analysis showed 15\% of changes in azoospermic patients in the studied group. Regarding changes in karyotype, Klinefelter syndrome is one of the most frequent genetic alterations in azoospermic patients. ${ }^{1,5-7,12,13}$ Y-chromosome microdeletions can be expected in approximately 15 to $20 \%$ of patients with NOA. The Y-chromosome is responsible for determining the male gender and features three regions known as AZFa, AZFb, AZFc. That is where the information for the production and maturation of sperm cells can be found. ${ }^{1,5-7,12}$ This evaluation is truly important because patients referred for assisted reproduction can transmit genetic disorders in the absence of genetic counseling. These patients are unlikely to benefit from varicocelectomy. ${ }^{4,6,8,11-13}$

On physical examination, identification of the vas deferens is fundamental. The presence of ectopic testicles or testicles with reduced volumes can be indicative of testicular failure or poor response to surgical procedure. These patients have a poorer prognosis. ${ }^{1,3,4,9}$

Until recently, the presence of varicocele was not acknowledged in these patients. Varicocele repair should not be considered in obstructive seminiferous tubules. It has a prevalence of $15 \%$ in the general population and occurs in 30 to $40 \%$ of infertile patients. ${ }^{1-4}$

A diagnosis is made during the physical exam with the patient being brought to a standing position, at room temperature. Doppler ultrasound can be used as a supplementary method..$^{1-3}$

Varicocele is a vascular disease that affects testicular veins. Its presence causes an inappropriate environment for the production and development of sperm. ${ }^{1-4}$ The disease can change the concentration, motility, morphology and structure of sperm DNA. ${ }^{-4}$

Pathological sperm vein reflux leads to the accumulation of $\mathrm{CO}_{2}$ and free radicals, lowering local concentrations of $\mathrm{O}_{2}$, which affects the functioning of Leydig cells and Sertoli cells. These cells are responsible for the production of testosterone and sperm, respectively. The varicocele can cause atrophy and calcification, hindering cell development and espermatogenesis. . $^{1-3,5,6,11-13}$

TABLE 1 Results of the sperm analysis after varicocelectomy.

\begin{tabular}{|c|c|c|c|c|c|}
\hline Varicocele & Cases treated surgically & $\%$ & Sperm positive $4^{\text {th }}$ month & Sperm positive $6^{\text {th }}$ month & Sperm positive $12^{\text {th }}$ month \\
\hline Bilateral & 10 & 40 & & & \\
\hline Left & 9 & 36 & 3 patients & 5 patients & 5 patients \\
\hline Right & 6 & 24 & & & \\
\hline Total & 25 & 100 & $12 \%$ & $20 \%$ & $20 \%$ \\
\hline
\end{tabular}

Note that even one year after surgery, the rate of sperm recovery was not greater than $20 \%$. 
In the studied group, 25 patients underwent bilateral procedure, although only ten presented bilateral varicocele veins. Out of 25 patients operated, five (20\%) benefited from varicocelectomy. Despite not reaching a minimum concentration of sperm, i.e. 20 million/mL, the recovery of spermatogenesis allowed the use of the patient's own semen for assisted fertilization techniques. $5,6,8-10,13$

Semen cryopreservation was suggested to five patients. None of the patients who recovered some production presented testicular volume reduction, noting that testicular volume reduction can be a prognostic of poorer results. ${ }^{1,89}$ Patients with no sperm found in the sperm control exam were referred to a human assisted reproduction service.

The five patients with genetic changes were advised of the possibility of choosing a sperm donor.

The other 15 patients with a diagnosis of idiopathic azoospermia were advised to undergo TESE, micro-TESE, TESA and PESA. These techniques are used to collect sperm from the testicle or epididymis. The sperm sample could be used for cryopreservation or assisted reproductive procedures (Table 2). 1,-9, 12-16

TABLE 2 Findings and actions after one year of varicocelectomy.

\begin{tabular}{|c|c|c|c|c|c|c|}
\hline $\begin{array}{l}\text { Varicoceles } \\
\text { operated }\end{array}$ & $\mathbf{n}$ & $\%$ & $\begin{array}{l}\text { Patients with } \\
\text { sperm retrieved }\end{array}$ & $\begin{array}{l}\text { With alterations in } \\
\text { the karyotype }\end{array}$ & $\begin{array}{l}\text { With Y-chromosome } \\
\text { microdeletions }\end{array}$ & Idiopathic patients \\
\hline Bilateral & 10 & 40 & & & & \\
\hline Left & 9 & 36 & 5 patients & 3 patients & 2 patients & 15 patients \\
\hline Right & 6 & 24 & & & & \\
\hline Total & 25 & 100 & $20 \%$ & $12 \%$ & $8 \%$ & $60 \%$ \\
\hline Actions & & & Cryopreservation of sperm & Use of sperm donor & & TESA PESA TESE \\
\hline
\end{tabular}

Note that $1 / 5$ of the operated patients can use their own sperm.

\section{Conclusion}

Patients with varicocele and azoospermia and without genetic changes or obstruction should be treated surgically with varicocelectomy.

Although small, the postoperative recovery of sperm would allow the couple to undergo assisted reproductive procedures without the need of a sperm donor. Thus, patients with NOA associated with varicocele veins should be made aware of the small chance of success in recovering sperm production after surgery, and of the purpose of surgery. ${ }^{7-13,16}$

\section{Conflict of interest}

The authors declare no conflict of interest.

\section{Resumo}

Pacientes com azoospermia e varicocele devem ser submetidos à cirurgia para recuperar a fertilidade?

Introdução: A varicocele é sabidamente uma das causas de infertilidade nos homens. A presença de veias espermáticas dilatadas pode criar um ambiente hostil para a espermatogênese. Isso é causa de baixa qualidade e quantidade da produção do esperma; em alguns casos, pode determi- nar uma ausência total de espermatozoides. O procedimento de varicocelectomia em pacientes com azoospermia não obstrutiva pode aumentar as taxas de espermatozoides na análise do sêmen. Uma taxa positiva para o esperma, mesmo se muito baixa, pode ser suficiente para permitir a coleta e destinar-se ao processo de fertilização in vitro. Isso sem a necessidade de usar esperma de doador.

Objetivo: Avaliar o aumento de espermatozoides em pacientes com varicocele associada à azoospermia não obstrutiva.

Método: Foram analisados os espermas de 25 pacientes azoospêrmicos não obstrutivos submetidos a procedimento de varicocelectomia bilateral com magnificação microcirúrgica.

Resultados: De um total de 25 pacientes, em três (12\%) ocorreu recuperação da contagem de espermatozoides quatro meses após o procedimento. Após um ano de procedimento, em cinco (20\%) ocorreu a recuperação.

Conclusão: Pacientes com ausência de espermatozoides e varicocele, sem alterações genéticas, devem ser submetidos a tratamento cirúrgico a fim de recuperar a produção de espermatozoides.

Palavras-chave: azoospermia, infertilidade, varicocele, cirurgia. 


\section{References}

1. Mulhall JP, Stalh PJ, Stember D. Varicocele. Clinical cares pathways in andrology. Philadelphia: Springer; 2013. p. 165-70.

2. Cozzolino DJ, Lipshultz Li. Varicocele as a progressive lesion: positive effect of varicocele repair. Hum Reprod Update. 2001; 7(1):55-8.

3. Fretz PC, Sandlow JI. Varicocele: current concepts in pathophysiology, diagnosis, and treatment. Urol Clin North Am. 2002; 29(4):921-37.

4. Male Infertility Best Practice Policy Committee of the American Urological Association; Practice Committee of the American Society for Reproductive Medicine. Report on varicocele and infertility. Fertil Steril. 2004; 82(Suppl 1):S142-5.

5. Inci K, Hascicek M, Kara O, Dikmen AV, Gürgan T, Ergen A. Sperm retrieval and intracytoplasmic regions sperm injection in men with nonobstructive azoospermia, and treated and untreated varicocele. J Urol. 2009; 182(4):1500-5.

6. Esteves SC, Glina S. Recovery of spermatogenesis after microsurgical subinguinal varicocele repair in azoospermic men based on testicular histology. Int Braz J Urol. 2005; 31(6):541-8.

7. Smit M, Romijn JC, Widhagen MF, Veldhoven JL, Weber RF, Dohle GR. Decrease sperm DNA fragmentation after surgical varicocelectomy is associated with increase pregnancy rate. J Urol. 2010; 183(1):270-4.

8. Abdel-Meguid T. Predictors of sperm recovery and azoospermia relapse in men with nonobstructive azoospermia after varicocele repair. J Urol. 2012; 187(1):222-6.
9. Lee JS, Park HJ, Seo JT. What is the indication of varicocelectomy in men with nonobstructive azoospermia? Urology. 2007; 69(2):352-55.

10. Pasqualotto F, Sobreiro BP, Hallak J, Pasqualotto EB, Lucon AM. Induction of spermatogenesis in azoospermic men after varicocelectomy repair: an update. Fertil Steril. 2006; 85(3):635-9.

11. Esteves SC, Miyaoka R, Roque M, Agarwal A. Outcome of varicocele repair in men with nonobstructive azoospermia: systematic review and meta-analysis. Asian J Androl. 2016; 18(2):246-53.

12. Dai RL, Hou Y, Li FB, Yue JM, Xi Q, Liu RZ. Varicocele and male infertility in Northeast China: Y chromosome microdeletion as an underlying cause. Genet Mol Res. 2015; 14(2):6583-90.

13. Tiseo BC, Russell PH, Tanrikut C. Surgical management of nonobstructive azoospermia. Asian J Urol. 2015; 2(2):85-91.

14. Franco G, Scarselli F, Casciani V, De Nunzio C, Dente D, Leonardo C, et al A novel stepwise micro-TESE approach in non obstructive azoospermia. BMC Urol. 2016; 16:20.

15. Saccà A, Pastore AL, Roscigno M, Naspro R, Pellucchi F, Fuschi A, et al Conventional testicular sperm extraction (TESE) and non-obstructive azoospermia: is there still a chance in the era of microdissection TESE? Results from a single non-academic community hospital. Andrology. 2016; $4(3): 425-9$

16. Bernie AM, Mata DA, Ramasamy R, Schlegel PN. Comparison of microdissection testicular sperm extraction, conventional testicular sperm extraction, and testicular sperm aspiration for nonobstructive azoospermia: a systematic review and meta-analysis. Fertil Steril. 2015; 104(5):1099-103. e.1-3. 